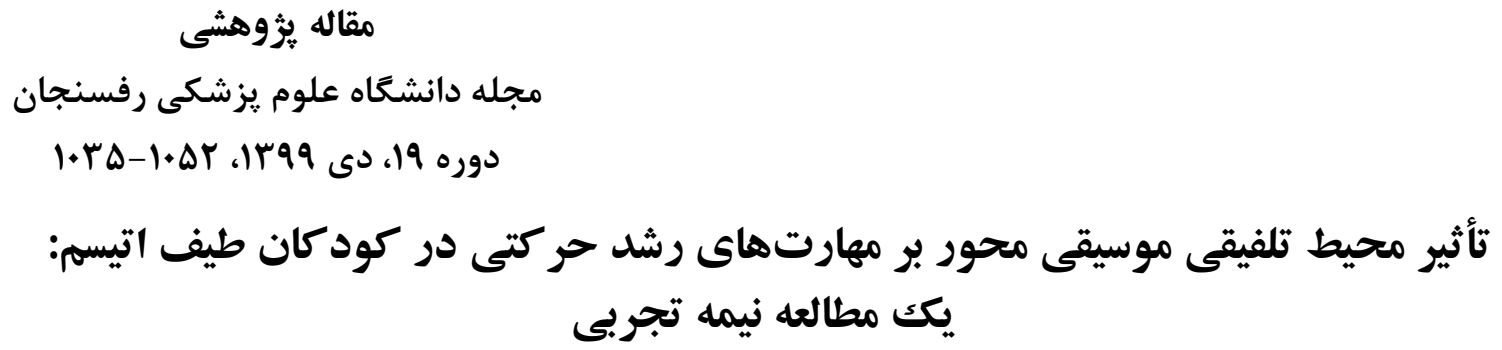

حسين مرادى مخلص'، شهاب الدين باقرى

بذيرش مقاله: 99/9/

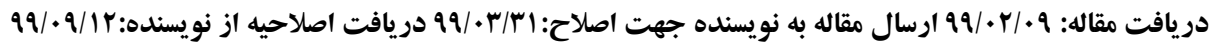
جكيده

زمينه و هدف: استفاده از مداخلات تلفيقى در كودكان اتيسم در حال گسترش است. علاقه كودكان اتيسم به موسيقى و

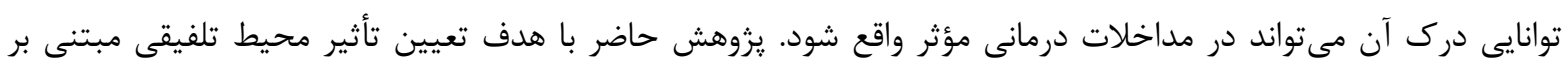
موسيقى بر مهارتهاى رشد حركتى در كودكان اتيسم انجام شد. مدان.

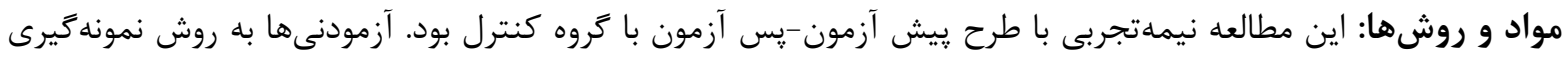

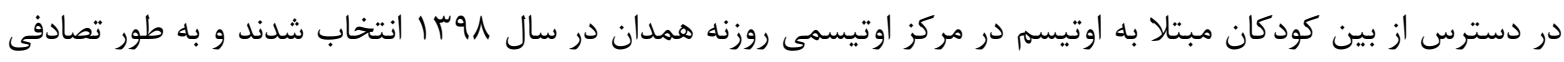

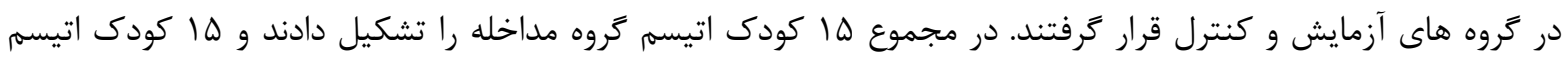

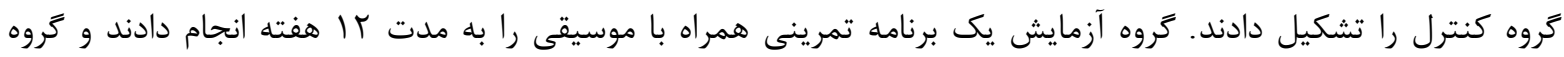

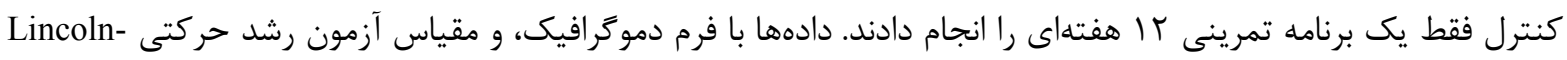

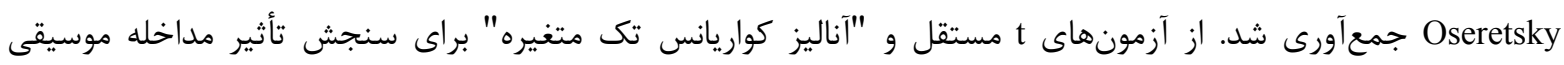
استفاده شد.

يافتهها: مشخص شد كه ميانكَين نمره مقياس Lincoln-oseretsky در گروه مداخله در يّ آزمون به طور معنى دارى بالاتر

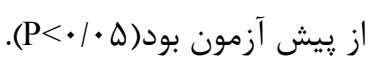

نتيجهَيرى: نتايج نشان داد كه محيط تلفيقى مبتنى بر موسيقى مىتواند در رشد مهارتهاى حركتى در كودكان مبتلا به اوتيسم مؤثر باشد. بنابراين، مداخله تلفيقى شامل موسيقى در كنار ساير روشهاى درمانى مىتواند منجر به نتايج مفيدى در بهبود عملكرد كودكان مبتلا به اتيسم شود. وازههاى كليدى: محيط تلفيقى، موسيقى، رشد حركتى، اتيسم

1- (نويسنده مسئول) استاديار گروه آموزشى علوم تربيتى، دانشكده علوم انسانى، دانشكاه بوعلى سينا، همدان، ايران تلفن:

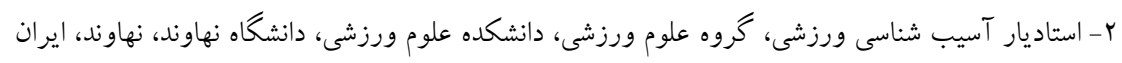


كودكان مبتلا به اتيسم مورد استفاده قرار گرفته است. با

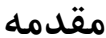

وجود عدم توجه به جهان خارج و حتى فقدان مهارتهاى كلامى در برخى موارد، اكثر كودكان داراى اختلال اتيسم علاقه زيادى به موسيقى دارند و حتى برخى از آنها توانايى فوق العادهاى در درك موسيقى و تفكيك صدا را دارند [9]. اجزاى موسيقى مانند زير و بمى صدا، سرعت، ريتم، الكَوى ملوديك نيازمند حركات فيزيكى است. بنابراين اجراى

موسيقى مىتواند متأثر از مهارتهاى حركتى باشد [ [1]. Fong و تأثير موسيقى درمانى گروهى به همراه آموزش مهارتهاى اجتماعى، ارتباطى و حركتى در كودكان طيف اتيسم را مورد آزمون قرار داد [11]. Dehghani و همكاران در يزوهشى به تأثير معنىدار بازىهاى ريتميك بر مشكلات توجه، حافظه و يادگيرى و عملكرد حسى حركتى در يسران داراى اختلال يادگيرى اشاره داشته است [1 I]. همجنين Katagiri در يزوهشى روشهاى مختلف آموزش حالات عاطفى در كودكان مبتلا به طيف اتيسم را مورد مطالعه قراد داد، نتايج نشان داد كه روش آموزشى تلفيق شده با موسيقى مؤثرتر از ساير روشها بود [سا]. در يك كارآزمايى بالينى Geretsegger و همكاران به مفيد و مؤثر بودن موسيقى درمانى بر مهارتهاى اجتماعى و ارتباطى كودكان مبتلا به اتيسم گزارش نموده است [If]]. به نظر مىرسد اجراى تلفيقى موسيقى و حركات بدنى در كنار هم و در شكل يك يروتكل تركيبى در كودكان مبتلا به اختلال اتيسم براى دستيابى به نتايج بهتر ضرورى به نظر مىرسد. لذا هدف مطالعه حاضر تعيين تأثير محيط تلفيقى موسيقى
اختلال طيف اتيسم (Autism Spectrum Disorder) يك اختلال پِيجيده عصبى-رشدى است كه نقص در الكوهاى اجتماعى، ارتباطات و الكوهاى محدود و كليشهاى رفتار، منافع و فعاليتها از علائم آن به شمار مىرود [1]. با وجود اينكه نقايص اجتماعى جزء خصوصيات بارز اختلال طيف اتيسم ذكر شده است، عملكرد حركتى در افراد مبتلا غير طبيعى به نظر مىرسد. مطالعات پيشين ضعف و عملكرد حركتى غير طبيعى در كودكان مبتلا به اختلال اتيسم در مقايسه با كودكان سالم را مورد تأييد قرار دادهاند [r-r]. علىرغم مشخص نبودن مكانيسم احتمالى بروز مشكلات حركتى، از اختلال در انتقال سروتونين، دويامين و كاما آمينوبيوتيريك اسيد در افراد مبتلا به عنوان مختل كننده

عملكرد حركتى در برخى مطالعات اشاره شده است [9-F]. ماهيت پِيجِيده اختلال اتيسم محققين را بر آن داشته تا در درمان آن از محيط هاى تلفيقى بهره گَيرند. بر اين اساس محيط تلفيقى با بازى و فعاليتهاى حركتى و بدنى نيز توجه متخصصان اتيسم را به خود جلب كرده است [V، V]. با توجه به اينكه كودكان اتيسم به روشهايى كه حركت، صدا و علامت كذارى به عنوان منبعى براى بيان، برقرارى ارتباط و ايجاد احساس مشترك توجه مى كنند، پيشنهاد شده است كه اين روشها بيشتر مورد توجه قرار گيرد [^]. موسيقى مىتواند سبب يكيار جهسازى حواس كودكان مبتلا به اتيسم شود. با توجه به ماهيت ريتميك آن يكى از مداخلاتى است كه در كنار ساير روشها براى بهبود سطح كيفى و مهارتى 
علاوه بر اين، عدم وجود تجربه قبلى آزمودنىها در آموزش همراه با موسيقى نيز مد نظر قرار گرفت. يس از انتخاب آزمودنىها، ابتدا اهداف تحقيق براى والدين تشريح شد و ملاحظات اخلاقى انجام يزوهش مانند اخذ رضايتنامه آكاهانه از والدين نمونهها قبل از شركت در مطالعه، گمنام ماندن نام آزمودنى، رازدارى و حفظ اسرار آزمودنى و دادن اطمينان به والدين آنها در مورد محرمانه بودن اطلاعات شخصى آزمودنىها، توجه به ايمنى آزمودنىها، عدم ايجاد محروميت و محدوديت در دريافت ساير خدمات سلامت، سودمندى و عدالت در اجراى يروتكل مطالعه از جمله ملاحظات اخلاقى اجراى اين يزوهش بود. اين مطالعه داراى كد اخلاق به شماره IR.NAHGU.REC.1398.001

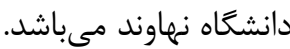

جهت اندازهيرى توانايىهاى ادراكى - حركتى از مقياس Lincoln-Oseretsky Motor Development Scale شد [ه1]]. اين مقياس براى اندازهگيرى مهارتهاى حركتى مختلف مانند تعادل ايستا و يويا، مهارت انخَشتان، هماهنگىى جشم، دست و فعاليتهاى عضلات بزرى دستها، بازوها، پاها و تنه در كودكان fl|f مى گيرد. فرم اصلاح شده اين مقياس شامل شش زير مقياس و צr ماده است. شش زير مقياس آن عبارتند از: ()

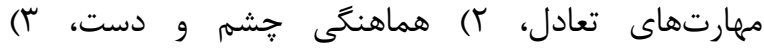
مهارتهاى دستى يويا (Dynamic manual skill’s)،

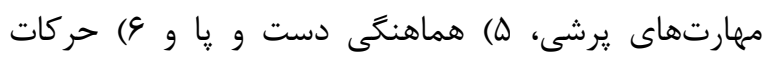
كرفتن و يرتاب كردن. در اين آزمون سعى شده است كه צب
محور بر مهارتهاى رشد حركتى در كودكان طيف اتيسم مى باشد.

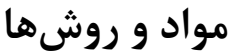

يزوهش حاضر از نوع تحقيقات نيمهتجربى با طرح ييش آزمون-يس آزمون با گروه كنترل بود. تعداد • ب نفر به روش نمونه مركز اتيسم روزنه همدان در سال ^وسا انتخاب و به طور تصادفى در دو گروه مداخله و كنترل (هر گروه ها نفر) جايكزين شدند. حجم نمونه با استفاده از نرمافزار Gower

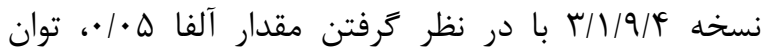

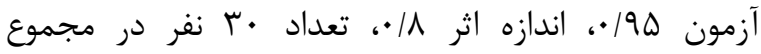
محاسبه و در هر گروه لها نفر در نظر گرفته شد. به منظور جلوگيرى و كاهش تورش احتمالى در طراحى و نتايج مطالعه، آزمودنىها به روش تخصيص تصادفى سازى ساده به دو گروه مداخله و كنترل (Simple randomization) تقسيم شدند. معيارهاى ورود به مطالعه عبارت بود از ابتلاء به اتيسم بر اساس ينجمين ويرايش راهنماى تشخيصى و آمارى اختلالات روانى ( Diagnostic and Statistical (Manual of Mental Disorders بر اساس يرسشنامه غربالگرى اختلالات نافذ رشدى (Autism screening scale questionnaire) سالم و يا اصلاح شده با وسيله كمكى، ثبت حس شنوايى طبيعى بر اساس آزمون ثبت حسى (Sensory profile) عدم وجود اختلالات ارتويديك و قلبى تنفسى، عدم بروز حمله تشنج در دو سال اخير و عدم مصرف دارو با عوارض حركتى. 
^ץ • ا تأثير محيط تلفيقى موسيقى محور بر مهارتهاى رشد حر كنى در كود كان طيف اتيسم

محل مركز اتيسم روزنه همدان اجرا كرد. كروه كنترل برنامه ورزشى را بدون استفاده از موسيقى انجام دادند و فعاليت مؤثر و منظم حركتى همراه با موسيقى نداشتند. به منظور پيشخَيرى و عدم تداخل برنامهها، و اطمينان از عدم تبادل اطلاعات نمونههاى دو گروه با يكديكر، گروه تجربى در روزهاى زوج و گروه كنترل در روزهاى فرد جهت اجراى يروتكلهاى اختصاصى در مركز حضور داشتند. محتواى مداخله ورزشى منتخب شامل پياده روى، جاگينَ و حر كات با توض همراه با موسيقى بود و مجموعاً حدود Dه دقيقه اجرا مىشد (جدول (). بخش ورزشى اين برنامه بر اساس توصيهها و دستوالعملهاى ويزه كودكان مبتلا به اتيسم طراحى شده و جهت پيش گيرى از بروز مشكلات اجرايى از مطالعات قبلى استفاده شده است

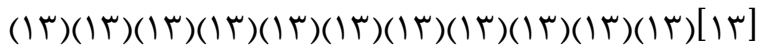
$(14)(14)(14)(14)(14)(14)(14)(14)(14)(14)(14)(14)$ )$(9)(1 \cdot)(1 \cdot)(11)(11)(11)(14)(14)(14)(14)(14)(14)$ (A تمرينات گروهى و سرد كردن تشكيل شده بود.
خرده آزمون بر اساس ترتيب دشوارى مرتب شوند. همه حركات بر اساس يك سيستم r نمرهاى ارزش كذارى مىشود. روش نمرهگذارى بدين صورت است كه نمره بخشهاى مختلف را محاسبه نموده و در انتها با هم جمع مى كنيم [ه 1]. تجربه نشان داده است كه كودكان • ا ساله و بالاتر كمتر در پينج ماده ابتدايى اين مقياس دجار مشكل مىشوند. در اين مورد مىتوان نمره كامل ينج ماده اول را به آنها داد و از ماده ششم شروع كرد. اعتبار (Reliability) اين آزمون در مطالعات مختلف ب9/. تا 99/• و روايى

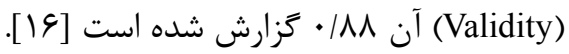
در مطالعه حاضر از نظرات افراد متخصص در رشتههاى مرتبط و مطالعات بيشين استفاده گرديد. به اين منظور پِ رِ از مطالعه و بررسىهاى دقيق و شكل اجرا توسط تيم تحقيق شامل: يك متخصص علوم تربيتى، يك متخصص علوم ورزشى و يك متخصص موسيقى يك برنامه TI هفتهاى، ب روز در هفته، يك روز در ميان و هر جلسه Dه دقيقه تنظيم شد. گروه مداخله برنامه تأييد شده را در مدت معين و به كمك يك كارشناس ورزشى در ساعت • "ا: •ا صبح و در

جلول ( - محتواى مداخله ورزشى منتخب (جاحينك، ياده روى و حركات با توب) جهت اجراى كروه تجربى در مدت •7 دقيقه

\begin{tabular}{|c|c|c|}
\hline زمان (دقيقه) & محتوا & بخش \\
\hline$\Delta$ & جاگينَ و يِاده روى & عرم كردن \\
\hline 10 & 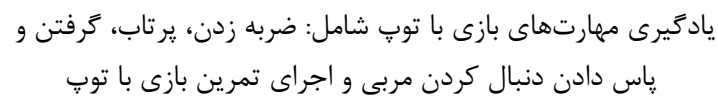 & آموزش تروهى \\
\hline$r$. & 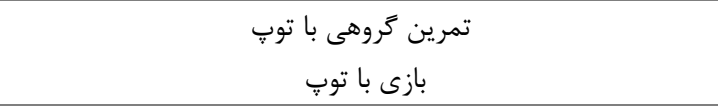 & تمرين گرووهى \\
\hline 10 & دست دادن (بزن قدش) مربيان، آزمودنى ها و والدين، & سرد كردن \\
\hline
\end{tabular}


آهنَّهاى مورد علاقه از طريق رايانه قابل حمل Toshiba) و و با استفاده از نرمافزار مخصوص Satellite L25 S1192) (Media player classic MPC.HC. 13.1359.0) جهت اطمينان از رسيدن حجم صداى مساوى به آزمودنىها،

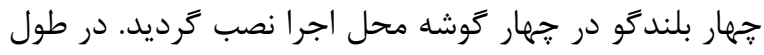
اجراى برنامه تمرينى به صورت مداوم از تشويقهاى زبانى

استفاده شد [9]. تجزيه و تحليل دادهها با استفاده از نرمافزار SPSS نسخه آ انجام شد. علاوه بر روشهاى آمار توصيفى، جهت بررسى طبيعى بودن دادهها از آزمون Shapiro-Wilk استفاده شد. همرجنين به منظور بررسى اثر مداخله از آزمون آمارى تحليل كوواريانس تك متغيره و آزمون t مستقل استفاده شد. سطح معنى دارى در آزمونها هـ • • در نظر كرفته شد. نتايج مشخصات جمعيت شناختى آزمودنىها شامل سن، قد، وزن و شاخص توده بدنى به صورت ميانگين و انحراف معيار در جدول | ارائه شده است (جدول (). نتايج آزمون shapiro-wilk (هD • • (PD). بنابراين براى تجزيه و تحليل دادهها از آزمونهاى يارامتريك t مستقل و آناليز كوواريانس تك متغيره استفاده شد.

نتايج آزمون t مستقل نشان داد كه دو گروه مورد مطالعه از نظر متغيرهاى جعيت شناختى مانند سن، قد، وزن و
در ابتدا مشخصات دموكرافيك آزمودنىها شامل: سن، قد، وزن و شاخص توده بدنى جمعآورى كرديد. معيار تعيين سن، شناسنامه آزمودنى بود. براى اندازهيرى وزن، قد و شاخص توده بدنى از ترازوى ديجيتالى ايستاده (مدل V99 ساخت كميانى Seca آلمان) بدون نياز به كاليبراسيون، و با قابليت اندازه گيرى شاخص توده بدنى ( Body Mass Index )، سنجش قد تا • r سانتىمتر، سنجش وزنى تا

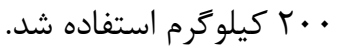
جهت اجراى مداخله ورزشى، آزمودنىهاى گروه تجربى در گروههاى ه نفره تعريف شدند. در طول اجراى هر مرحله آزمودنى مجبور بود براى گرفتن و ياس دادن توڤ از ه نفر از همسالان خود عبور كند و به طور طبيعى به صورت فيزيكى و جشمى ارتباط ايجاد مىكردند. براى تشويق بيشتر كودكان از والدين آنها خواسته شد كه در جلسات تمرين و در كروههاى همسان شركت كنند. براى انتخاب موسيقى قبل از شروع آزمون فهرستى متشكل از ها آهنگ در اختيار آزمودنىها قرار كرفت و از بين آنها و بر اساس اقبال آزمودنىها ها آهنگ انتخاب شد. با توجه به اين كه ضرباهنگ (Tempo) ضرباهنگ و حجم صدا در آهنخَهاى ارائه شده يكسان در نظر گرفته شد. به منظور دستيابى به فوايد بيشتر برنامه ورزشى، با حدود •و درصد شدت ضربان قلب بيشينه تعريف شد. علاوه بر آن با توجه به اينكه موسيقى انخيزشى غالباً

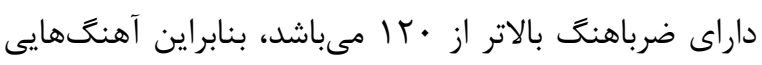
انتخاب شده در سبك تكنو و با ضرباهنَ بالاتر از • rا بود. 


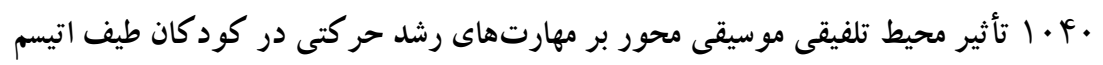

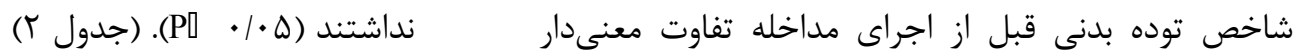

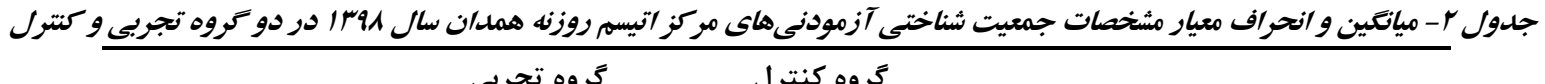

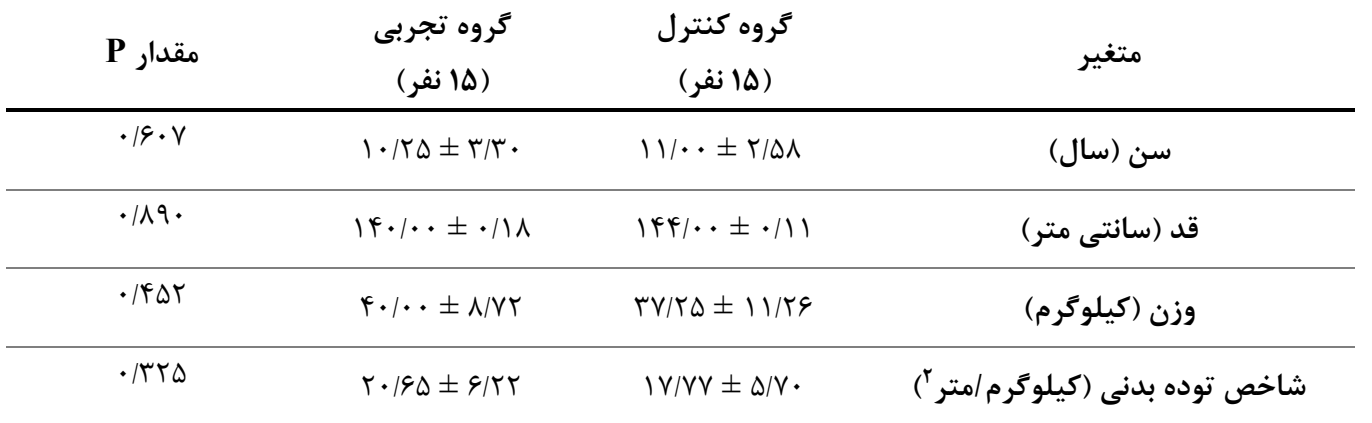

آزمون toتقل، •/

متغير وابسته ارتباط خطى و همگنى ركرسيون وجود دارد

نتايج نشان مىدهد كه اثر متقابل بين گروه و متغير

(نمودار ().

همراه در خرده آزمون تعادل معنى دار نيست (P=./ITY).

اين نتيجه حاكى از آن است كه بين متغير تصادفى همراه و

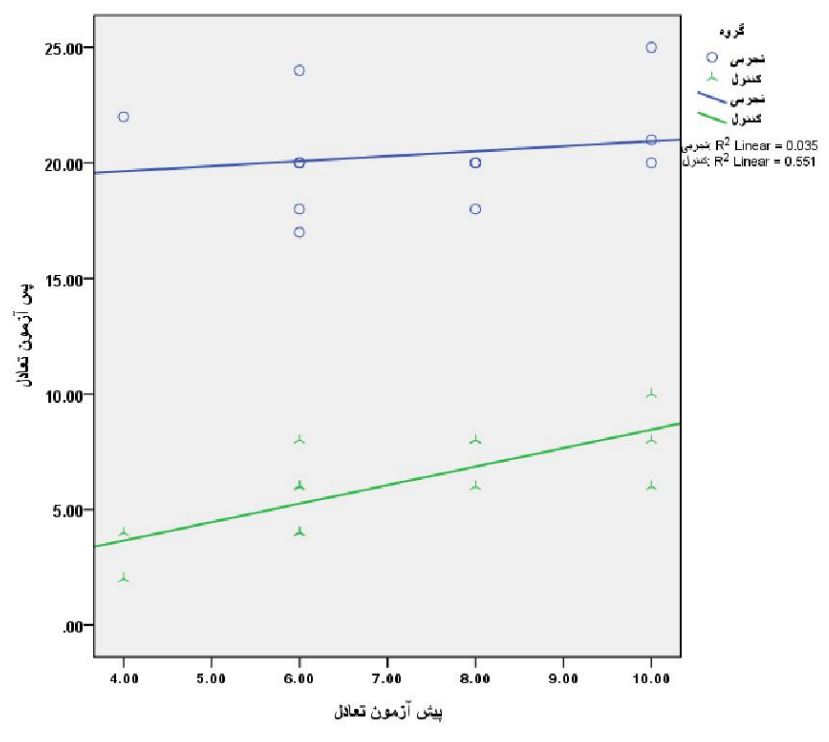

نمودار ا - همكنى شيب ركرسيون در خرده آزمون تنادل

نتايج جدول ץ نشان مىدهد كه يس از تعديل نمرات واقع ميزان تأثير مداخله تلفيقى آ درصد بوده است.

رِيش آزمون در متغير مهارتهاى تعادلى، مداخله تلفيقى بنابراين از نتايج فوق استنباط مىشود برنامه تركيبى ورزش

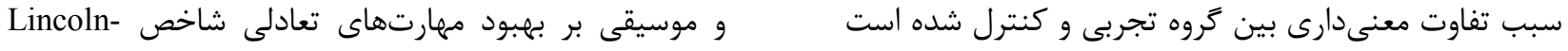

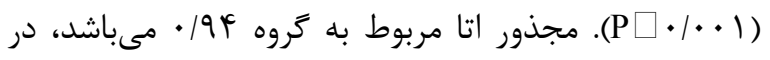


oseretsky جدول بـ -نتايج تحليل آمارى متغير مهارت هاى تعادلى در دو كروه تجربع و كنترل

\begin{tabular}{|c|c|c|c|c|c|c|}
\hline مجذور اتا & Pقدار P P & $\mathbf{F}$ & ميانكَين و انحر اف استاندارد & 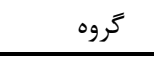 & & متغير \\
\hline \multirow{4}{*}{.194} & \multirow{4}{*}{$\square \cdot / \cdot \cdot 1$} & \multirow{4}{*}{$r t / 1 F^{f}$} & $V / r \cdot \pm I / A r$ & ي پيش آزمون & \multirow{2}{*}{ 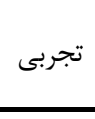 } & \multirow{4}{*}{ لمهارتهاى تعادلى } \\
\hline & & & $r \cdot / r r \pm r / l r$ & بֶ آزمون & & \\
\hline & & & $9 / 94 \pm 1 / \pi 9$ & يِيش آزمون & \multirow{2}{*}{ كنترل } & \\
\hline & & & $\varepsilon / \cdot \pm r / l f$ & يِ آزمون & & \\
\hline
\end{tabular}

آزمون آنكوا، 0٪•

متغير تصادفى كمكى و متغير وابسته ارتباط خطى و همخنى ركرسيون وجود دارد (نمودار ب).

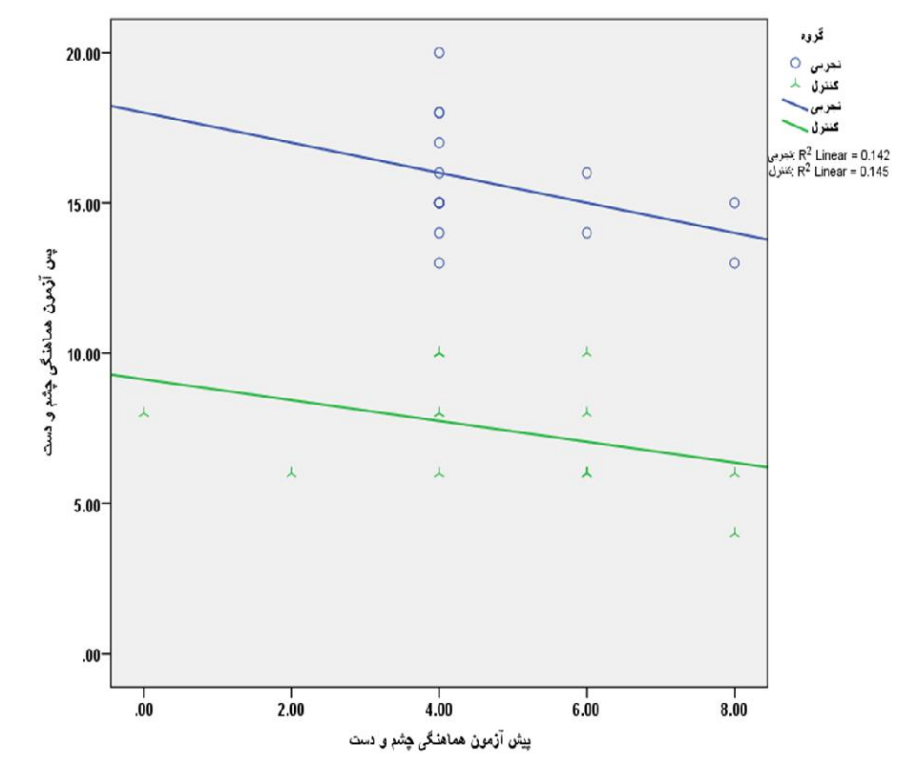

نمودار ب - همكنى شيب ركرسيون در خرده آزمون هماهنكى جشمر و دست
مجذور اتا مربوط به گروه AY| • مىباشد، در واقع ميزان تأثير موسيقى 1 درصد بوده است. بنابراين از نتايج فوق نتيجه كرفته مىشود مداخله تلفيقى طراحى شده بر بهبود هماهنگى جشم و دست در شاخص Lincoln-oseretsky

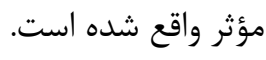

يافته ها نشان مىدهد اثر متقابل بين متغير همراه و متغير وابسته در خرده آزمون هماهنگى جشم و دست معنى

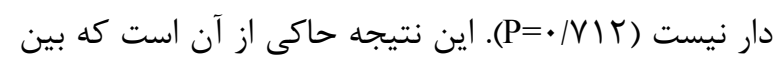

نتايج مربوط به آزمون تحليل كوواريانس براى خرده آزمون هماهنكى جشم و دست در جدول \& ا ارائه شده است.

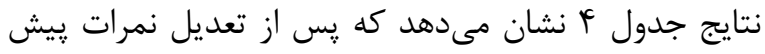
آزمون در متغير هماهنكى جشم و دست، تفاوت معنىدار

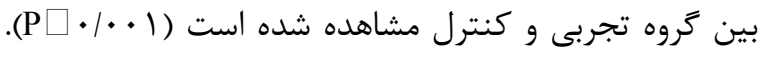


Tr F • أأثير محيط تلفيقى موسيقى محور بر مهارتهاى رشد حر كنى در كود كان طيف اتيسم

جلدول ع- نتايج تحليل آمارى متغير هماهنكى حشمر و دست دركروه هاى تجربى و كنترل

\begin{tabular}{|c|c|c|c|c|c|c|}
\hline مجذور اتا & Pقدار P P & $\mathbf{F}$ & ميانكَين و انحراف استاندارد & كروه & & متغير \\
\hline \multirow{4}{*}{ - /AF } & \multirow{4}{*}{$\square \cdot / \cdot \cdot 1$} & \multirow{4}{*}{ IFVIGT } & $r / \Lambda \cdot \pm 1 / q v$ & يِيش آزمون & \multirow{2}{*}{ 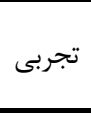 } & \multirow{4}{*}{ جشم و دسنتى } \\
\hline & & & $10 / 9 \cdot \pm 1 / 9 r$ & عِ آزمون & & \\
\hline & & & $r / q r \pm r / l r$ & بيش آزمون & \multirow{2}{*}{ كنترل } & \\
\hline & & & $V / I \pm r \& / 9 r$ & يس آزمون & & \\
\hline
\end{tabular}

آزمون آنكوا، 0

يافتها نشان مىدهد كه اثر متقابل بين دو متغير همراه و تصادفى كمكى و متغير وابسته ارتباط خطى و همكنى

وابسته در خرده آزمون مهارتهاى دست معنى دار نيست ركرسيون وجود دارد (نمودار ب).

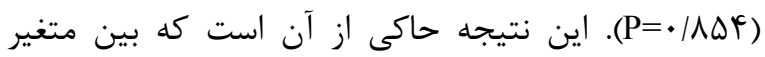

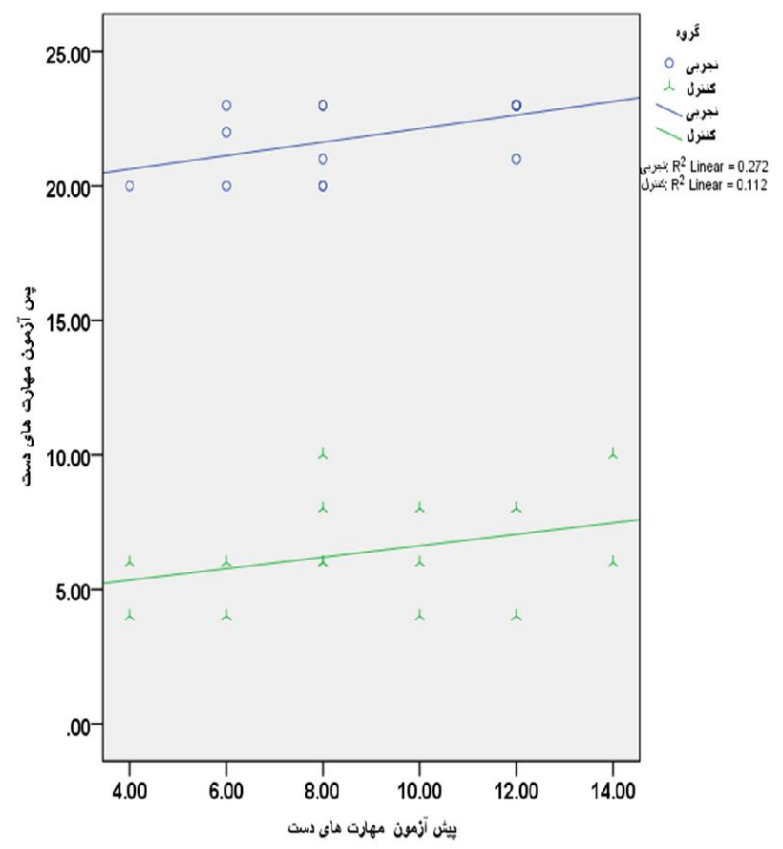

نمودار بر- همكنى شيب ركرسيون در خرده آزمون مهارتهاى دست

99/ • مىباشد، در واقع ميزان تأثير برنامه تمرينى 9 درصد

بوده است. بنابراين از نتايج فوق نتيجه گرفته مىشود

مداخله تلفيقى طراحى شده سبب بهبود مهارتهاى دست

در شاخص Lincoln-oseretsky در گروه تجربى شده است.
نتايج مربوط به آزمون تحليل كوواريانس براى خرده آزمون مهارتهاى دست كزارش شده در جدول ه نتايج نشان مىدهد كه پِ از تعديل نمرات پِيش آزمون در متغير مهارتهاى دست، تفاوت معنىدار بين گروه تجربى و كنترل مشاهده شده است (1 (PD ·). مجذور اتا مربوط به گروه 
جلدول ه- نتايج تحليل آمارى متغير مهارتهاى دست در دو كروه تجربى و كنترل

\begin{tabular}{|c|c|c|c|c|c|c|}
\hline مجذور اتا & مقدار P P & $\mathbf{F}$ & ميانتين و انحراف استاندارد & كروه - ك & & متغير \\
\hline \multirow{4}{*}{.199} & \multirow{4}{*}{$\square \cdot / \cdot \cdot 1$} & \multirow{4}{*}{$9 q T / 4)$} & $\Lambda / r \pm r q / \Lambda)$ & يِيش آزمون & \multirow{2}{*}{ 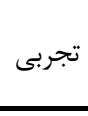 } & \multirow{4}{*}{ دمست دهاى } \\
\hline & & & $\Gamma / / \Lambda \varphi \mid \pm / r \Delta$ & يس آزمون & & \\
\hline & & & $r / 9 r \pm r / / F$ & ي بيش آزمون & \multirow{2}{*}{ كنترل } & \\
\hline & & & $\Lambda / q r \pm r / 19$ & يُ آزمون & & \\
\hline
\end{tabular}

آن كونه كه از نتايج بر مى آيد اثر متقابل بين متغير همراه متغير تصادفى كمكى و متغير وابسته ارتباط خطى و همحنى

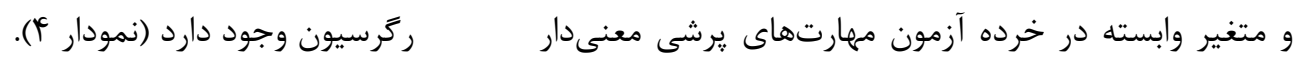

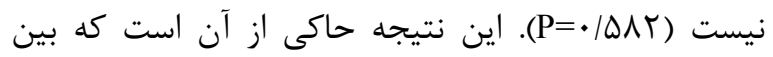

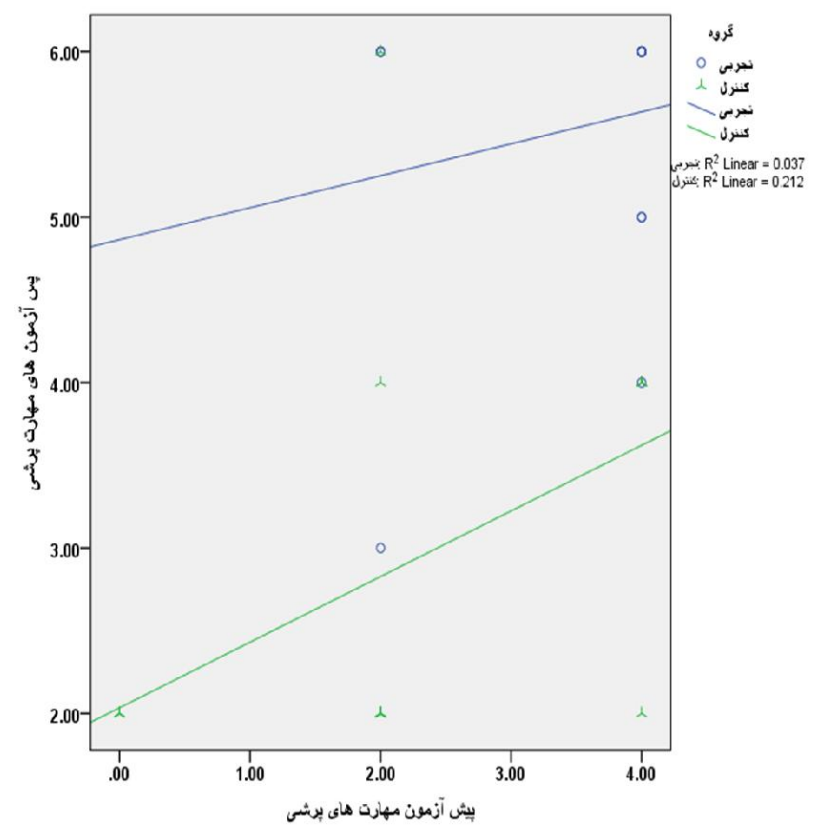

\section{نمودار ع- همكنى شيب ركرسيون در خرده آزمون معارت هاى يرشى}

مربوط به تروه 9\&/• مى باشد، در واقع ميزان تأثير يروتكل تمرينى q q درصد بوده است. بنابراين از نتايج فوق نتيجه گرفته مىشود تركيب موسيقى و ورزش سبب بهبود مهارتهاى يرشى در شاخص Lincoln-oseretsky در گروه تجربى شده است.
نتايج مربوط به آزمون تحليل كوواريانس براى خرده آزمون مهارتهاى يرشى در جدول \& به نمايش درآمده است. اين نتايج نشان مىدهد كه يس از تعديل نمرات يِيش آزمون در متغير مهارتهاى يرشى، تفاوت معنىدار بين گروه تجربى و كنترل مشاهده شده است (1 (P] • P]). مجذور اتا 
Fץ + • أثير محيط تلفيقى موسيقى محور بر مهارتهاى رشد حر كتى در كود كان طيف اتيسم

جلول I-نتايج تحليل آمارى متغير مهارتهاى برشى در دو كروه تجربى و كنترل

\begin{tabular}{|c|c|c|c|c|c|c|}
\hline مجذور اتا & Pقدار Pق & $\mathbf{F}$ & ميانكين و انحراف استاندارد & 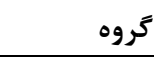 & & متغير \\
\hline \multirow{4}{*}{$\cdot / 49$} & \multirow{4}{*}{$\square \cdot / \cdot \cdot 1$} & \multirow{4}{*}{$r \& / 11$} & $r / 4 \varphi \pm . / 91$ & ي پِيش آزمون & \multirow[b]{2}{*}{ 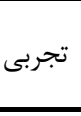 } & \multirow{4}{*}{ ميرشى مهارتى } \\
\hline & & & $\Delta / \Delta r \pm 1 / 91$ & يس آزمون & & \\
\hline & & & $r / r \varphi \pm 1 / 4 \Lambda$ & بيش آزمون & \multirow{2}{*}{ 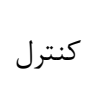 } & \\
\hline & & & $r / 9 Y \pm 1 / T V$ & يس آزمون & & \\
\hline
\end{tabular}

آزمون آنكوا، 0••

يافتها نشان مىدهد كه اثر متقابل بين دو عامل مستقل تصادفى كمكى و متغير وابسته ارتباط خطى و همخنى

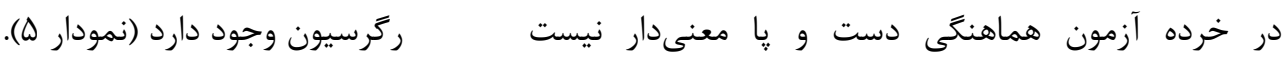

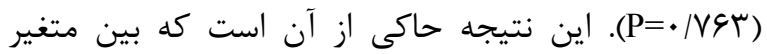

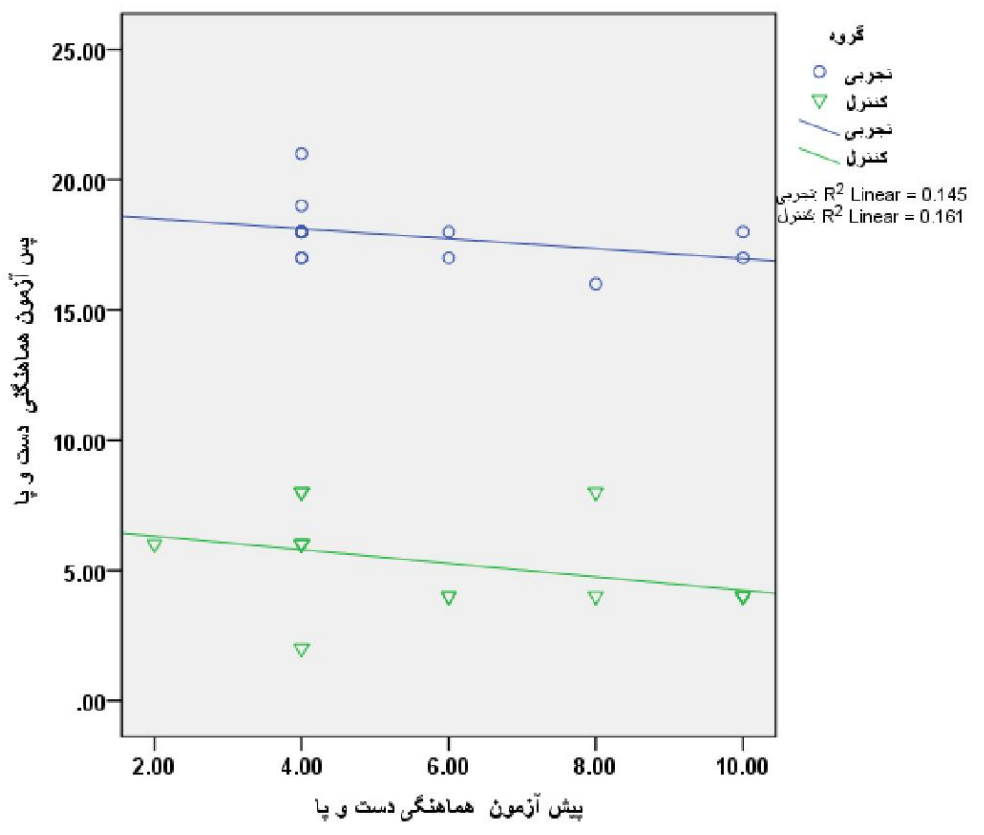

نمودار ه- همتنى شيب ركوسيون در خرده آزمون هماهنكى دست و ٍٍ

به گروه ه 9/• مىباشد، در واقع ميزان تأثير مداخله تمرينى ه9 درصد بوده است. بنابراين از نتايج فوق نتيجه كرفته مىشود تركيب موسيقى و ورزش سبب بهبود هماهنكى

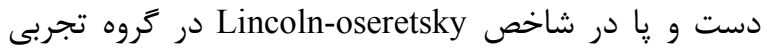
شده است.
نتايج مربوط به آزمون تحليل كوواريانس براى خرده آزمون هماهنكى دست و پا در جدول V ارائه شده است. نتايج نشان مىدهد كه يس از تعديل نمرات يیش آزمون در

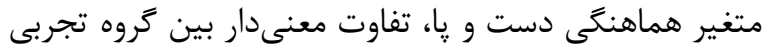
و كنترل مشاهده شده است (1 (P] + (P). مجذور اتا مربوط 
جلدول Y- نتايج تحليل آمارى متغير هماهنكى دست و با دو دو كروه تجربى و كنتل

\begin{tabular}{|c|c|c|c|c|c|c|}
\hline مجذور اتا & مقدار P P P & $\mathbf{F}$ & ميانغين و انحراف استاندارد & 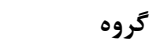 & & متغير \\
\hline \multirow{4}{*}{$\cdot / 90$} & \multirow{4}{*}{$\square \cdot / \cdot \cdot 1$} & \multirow{4}{*}{$\Delta \Delta V / \Lambda F$} & $\Delta / r r \pm r / T r$ & ييش آزمون & \multirow{2}{*}{ 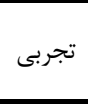 } & \multirow{4}{*}{ دست و راهنى } \\
\hline & & & IV/AG $\pm I / I T$ & يس آزمون & & \\
\hline & & & $9 / r \varphi \pm r / \Lambda)$ & ي ريش آزمون & \multirow{2}{*}{ كنترل } & \\
\hline & & & $\Delta / r \cdot \pm 1 / \Lambda T$ & يس پآزمون & & \\
\hline
\end{tabular}

بر اساس يافتهاى يزوهش اثر متقابل بين دو عامل متغير تصادفى كمكى و متغير وابسته ارتباط خطى و همكنى

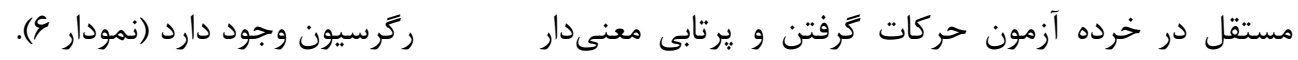
نيست (Pa) (P=). اين نتيجه حاكى از آن است كه بين

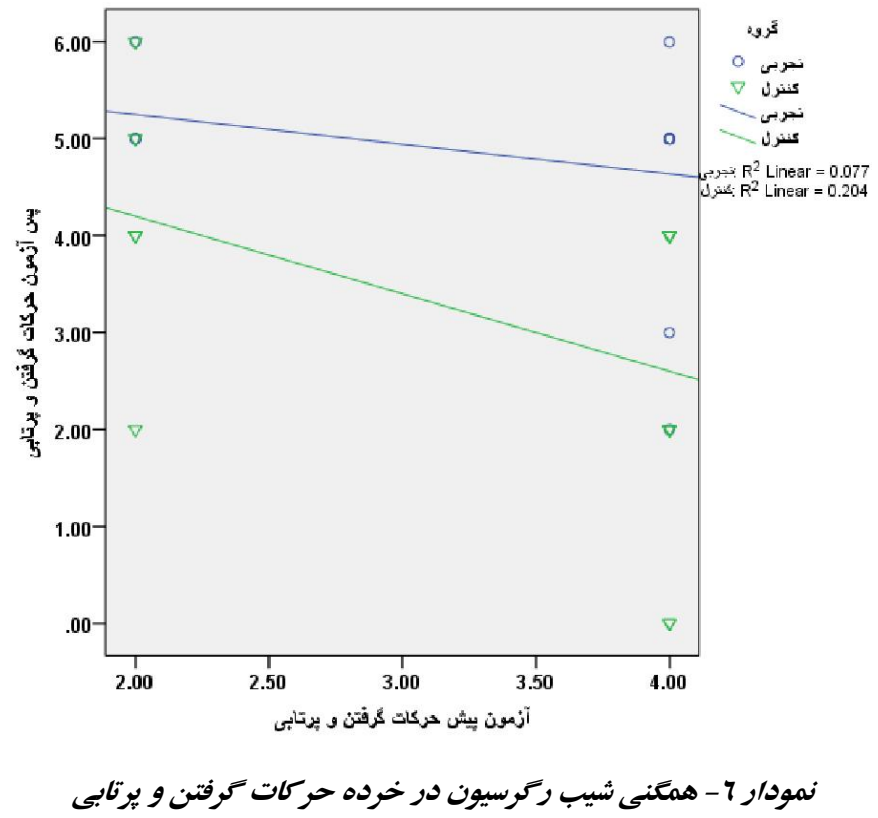

مربوط به گروه r r/ • مىباشد، در واقع ميزان تأثير مداخله تلفيقى זr درصد بوده است. بنابراين از نتايج فوق نتيجه كرفته مىشود تركيب موسيقى و ورزش سبب بهبود حركات گرفتن و يرتابى در شاخص Lincoln-oseretsky در گروه تجربى شده است.
نتايج مربوط به آزمون تحليل كوواريانس براى خرده آزمون حركات گرفتن و يرتابى در جدول ^ ارائه شده است. نتايج نشان مىدهد كه يس از تعديل نمرات يِيش آزمون در متغير حركات گرفتن و يرتابى، تفاوت معنىدار بين گروه تجربى و كنترل مشاهده شده است (1 + • • P[). مجذور اتا 
4 • ا تأثير محيط تلفيقى موسيقى محور بر مهارتهاى رشد حر كتى در كود كان طيف اتيسم

جلول 1- نتايج تحليل آمارى متغيرحركات كرفتن و برتابى در دو كروه تجربى و كنترل

\begin{tabular}{|c|c|c|c|c|c|c|}
\hline مجذور اتا & Pقدار P P & $\mathbf{F}$ & ميانكَين و انحراف استاندارد & تروه & & متغير \\
\hline \multirow{4}{*}{. } & \multirow{4}{*}{$\square \cdot / \cdot \cdot$} & \multirow{4}{*}{ IT/VF } & $r / 4 \varphi \pm \cdot / 91$ & ييش آزمون & \multirow{2}{*}{ 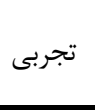 } & \multirow{4}{*}{ 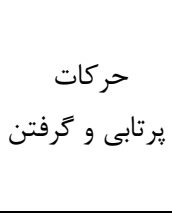 } \\
\hline & & & $r / \Lambda \cdot \pm 1 / \cdot \Delta$ & يس آزمون & & \\
\hline & & & $r / 9 r \pm r / l r$ & بيش آزمون & \multirow{2}{*}{ كنترل } & \\
\hline & & & $|r / V r \pm r /|$ & 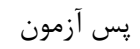 & & \\
\hline
\end{tabular}

آزمون آنكوا، 0٪•

سويى تحقيقات كذشته نشان داده است كه موسيقى آهسته به كودكان اتيسم كمك مى كند تا رفتارهاى خود را تنظيم

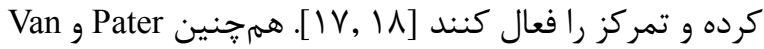
بperen ᄉ ساله مبتلا به اتيسم بهبود معنىدار رفتارهاى اجتماعى و حركتى با استفاده از مقياس راس كزارش VISK Scores كردماند [19] در توجيه علت تأثير مثبت موسيقى با حركات ورزشى بر مهارتهاى رشد حركتى مىتوان به وجود رابطه و همبستخى مثبت بين عملكرد مناسب در يردازش و اجراى ريتميك و برنامهريزى و عملكرد حركتى اشاره كرد كه در برخى مطالعات ذكر شده است [•r-9 19]. همرجنين در توضيح تأثير مثبت حركات ريتميك بر توانايىهاى ادراكى حركتى مىتوان بيان كرد كه تمرينهاى ريتميك يا بازى همراه با موسيقى يكى از روشهاى ورزشى جالب براى كودكان و به ويزه نوجوانان است. حركات ريتميك افزون بر اينكه ابزار مؤثرى براى آموزش و تمرين مهارتهاى حركتى پايه فراهم مى كند، مىتواند بر فرآيندهاى شناختى، توجه، ادراك، تمركز حواس و رشد ارتباطات فردى و مهارتهاى اجتماعى نيز اثركذار باشد. از آنجايى كه اين حركات اغلب همراه با موسيقى شاد و همكانى انجام مىشود، كودكان انخيزه بيش

در اين مطالعه تأثير يك محيط تلفيقى موسيقى محور بر بهبود مهارتهاى حركتى در كودكان مبتلا به اتيسم مورد بررسى قرار گرفت. يافتههاى اين يزوهش نشان مىدهد كه يك مداخله تلفيقى بر روى شاخصهاى رشد حركتى مقياس مؤثر واقع شده است. اين نتايج حاكى از آن است كه مهارتهاى تعادلى، هماهنكى קشم و دست، مهارتهاى دست، مهارتهاى ڤُشیى، حركات يرتابى و كرفتن در گروه تجربى در مقايسه با گروه كنترل بهبود

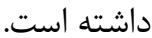

يافتههاى يزوهش حاضر با مطالعات Dehghani و

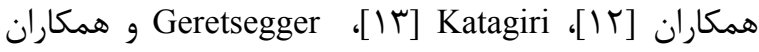

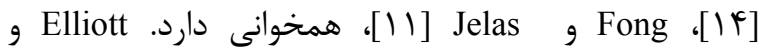
همكاران اثرات مثبت بسيارى در شرايط استفاده از موسيقى با ضرباهنگَهاى بالا و يايين در مقايسه با وضعيت بدون موسيقى گَزارش كردهاند. افزايش معنىدار ضربان قلب و سرعت دويدن در هر دو وضعيت موسيقى استفاده شده در اين مطالعه مشاهده شده است [IV] Woodman و همكاران نشان دادند موسيقى با سرعت پايين نسبت به موسيقى با ضرباهنََهاى سريعتر كودكان مبتلا اتيسم را بيشتر براى تحرك و فعاليت بدنى با شدت بالا ترغيب مىكند [9]. از 
در كودكان اتيسم فعاليتهاى موسيقى باعث :بردازش

ديدارى-كلامى و برنامه ريزى حركتى مىشود [IV]

در بين خرده آزمونها، مهارتهاى تعادلى به طور مستقيم

با توانايى شنوايى مرتبط است، در حالى كه هماهنگَى حركات ظريف و ريتميك با باز توليد الكوهاى ريتميك در ارتباط است. علاوه بر اين، يروهشهاى كذشته نشان دادهاند كه بين مهارتهاى يرشى و شنوايى همبستخى مثبت وجود داشته است [•!]. با توجه به تئورى ادغام حسى، سيستم لامسه مسئول درك تصويرى و برنامهريزى حركت است. محققان دو حقيقت را در نظر كرفتند: الف) ريتم جزء برجستهتر موسيقى است كه با رفتار حركتى فرد ارتباط دارد و نشان دهنده ياسخ سيستم حسى حركتى به محركهاى شنوايى است و ب) ادراك به تمام تجربيات حسى اشاره دارد كه از تحريك اندامهاى حسى مانند جشم و گَش ايجاد مىشود. بازىهاى مبتنى بر حركت براى كشف دورنى و فعال نمودن توانايىهاى مغزى كودكان كوتاهترين راه را بر مى و مهممترين ابزار عصب شناختى رشد در دوران كودكى تلقى كرد. ماهيت وجودى حركت و بازىهاى قانونمند خصوصياتى مانند ريتم، هماهنگى، آهنگ و موسيقى در خود نهفته دارد. همرجنين بازىهاى قانونمند قابليتهاى حسى و حركتى كودكان را به منصه ظهور مىرسانند [Tr]. شركت در فعاليتهاى بدنى جمعى زمينهساز ايجاد ارتباط با ديكران شده و فرد را از نظر اجتماعى فعالتر مى كند. از ديغر دلايل احتمالى مؤثر بودن مداخله تلفيقى در مطالعه حاضر استفاده از برنامه تمرينى هوازى بود، مطالعات نشان دادهاند كه يكى از بهترين روشها براى تحريك كردن
ترى براى شركت در آنها دارند. با توجه به اين ويزگىها، كودكان و نوجوانان براى انجام اين گونه حركات فيزيكى علاقه زيادى دارند. تمرينات همراه با موسيقى تأثير قابل توجهى در شكل گيرى قشر مغز دارد و از آنجا كه راههاى مختلف حساسى وجود دارد كه بخشى از آن محدوديتهاى عصبى در كودكان با اختلالات يادگيرى است، با استفاده از موسيقى و ريتم در شكل حركات فيزيكى هارمونيك به طور همزمان شاخههاى عصبى را افزايش مىدهد. به عبارت ديكر، تحرك طولانى مدت موجب افزايش سينايس مغز مىشود و در نهايت منجر به درك حساسيت در سطوح بالا مىشود

از ديگر توجيهات احتمالى اثركذارى تمرينات ورزشى همراه با موسيقى و كسب نتايج پِيش رو اين است كه جنبههاى موزيكال بازىهاى ريتميك باعث ايجاد و تقويت روابط اينترنرورون در مغز از طريق فرآيندى شبيه به روند تكميل مغز مىشود. به عبارت ديخر، در محيط حركت همراه با موسيقى، جرخههاى پيام رسانى عصبى ايجاد مىشود كه قسمتهاى فوقانى سيستم عصبى را كه به حافظه و شناخت مربوط مىشود، تحريك مىكنند [III]. در واقع بهبود در هماهنكى يِيامهاى عصبى مىتواند منجر به بهبود در كنترل وضعيت بدنى و تعادل و هماهنگگى در افراد مبتلا به اتيسم شود [91]. فعاليتهاى موسيقى اغلب براى حركت مورد استفاده قرار مى گيرد و باعث رشد اعضاى حسى_حركتى دست، پا و بدن در كودكان مىشود [اr/]. كوش دادن به موسيقى حركتهاى موزون همراه با آن سبب بهبود مهارتهاى حركتى، افزايش هماهنگى جشم و دست، تقويت و كنترل حركات و بهببود دامنه حركتى مفاصل خواهد شد. 
تنظيم اثرات به احتمال زياد فرصتهايى را براى ايجاد شرايط مشترك و ايجاد سريع پيشرفت مهارتهاى تعامل اجتماعى در كودكان مبتلا به اتيسم ايجاد مى كند [ [Y]]. از محدوديتهاى مطالعه حاضر عدم كنترل فعاليتهاى روزانه و عدم پييگيرى بلند مدت مداخله اشاره كرد كه قابليت تعميم يذيرى نتايج آن را محدود مى كند. اين مطالعه يكى از مطالعات تلفيقى موسيقى محور مىباشد كه در آن به صورت همزمان هم از برنامههاى ورزشى و هم بازى و سركرمى در كنار موسيقى و به صورت گروهى و با مشاركت والدين انجام شده است كه در داخل كشور كمتر به آن يرداخته شده است. از اين رو پيشنهاد مىشود برنامه تلفيقى حاضر در نمونههاى ديخر اجرا شود تا قابليت تعميم پذيرى آن افزايش

\section{نتيجهدَيرى}

به طور كلى نتايج مطالعه حاضر نشان داد كه I I هفته مداخله تلفيقى موسيقى محور سبب بهبود شاخصهاى رشد حركتى مقياس Lincoln-oseretsky در كودكان مبتلا به اختلال اتيسم شده است. لذا با لحاظ نمودن محدوديتهاى موجود در افراد مبتلا به اختلال اتيسم استفاده از اين برنامه و برنامههاى مشابه مىتواند راه حل مناسبى براى ارتقاء مهارتهاى حركتى در افراد مبتلا باشد.

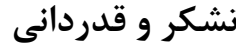

نويسند دانشگاه نهاوند به جهت تأمين هزينههاى مالى طرح و به طور خاص از كودكان و خانوادههايى كه در اين يزوهش شركت داشتهاند، تقدير و تشكر نمايند.
سلولهاى مغز و در نتيجه افزايش هوش، ورزشهاى هوازى است. اصول اساس موسيقى درمانى شامل نظريه نوروآندوكرين، نظريه رزونانس، مكانيسم روانشناختى و و روسي نظريه طيف انرزى موج موسيقى است [سז]. امواج صوتى موسيقى بر روى سيستم ليمبيك مغز و تشكيلات مشبك ساقه مغز عمل كرده و از اين طريق تحريكيذيرى سلولهاى عصبى را بهبود مىبخشد. موسيقى محركهاى شنوايى ״يجֶيده را از طريق ريتم و ملودى شكل مىدهد [TI]. موسيقى درمانى مىتواند سبب ارتقاء رشد مغز در كودكان شود در همين حال توسعه و رشد قابليتهاى مختلف از جمله توجه، حافظه، تخيل، تفكر انتزاعى، و زبان را تسهيل مى كند. مداخلات موسيقى مىتواند سبب افزايش حس مشاركت كودكان مبتلا به اتيسم در يادگيرى و فعاليتهاى اجتماعى شود. علاوه بر اين، آواز خواندن، بازى كردن با آلات موسيقى، آموزش ريتم، بازىهاى موسيقى و گوش دادن به موسيقى مىتواند براى بازسازى، نَمهدارى و ارتقاء ذهنى و سلامت جسمانى مورد استفاده قرار گيرد [YF]. در موسيقى درمانى از موسيقى و احساسات عاطفى استفاده مىشود تا لحظات همعام سازى، كار بر روى ادغام حسى و تأثير گذارى بر تنظيم و ايجاد لحظههاى عاطفى، در حال ظهور انجام شود. لذا تصور بر اين است كه احساسات موفقيت آميز كه در موسيقى درمانى بروز ِيدا مىكند باعث افزايش فرصتهاى كودى براى بهبود خودآكاهى، تجربه توجه

مشترك و متقابل اجتماعى و تقويت ارتباط مىشود [CS]. به طور كلى مىتوان رويكردهاى درمانى ارائه شده نشان دهنده آكَاهى نسبت به يردازش حسى، حركت و كنترل حركات، هماهنَ سازى در حركت و احساسات و همجنين 


\section{References}

[1] Association AP. Diagnostic and statistical manual of mental disorders (DSM-5®): American Psychiatric Pub; 2014.

[2] Jones RA, Downing K, Rinehart NJ, Barnett LM, May T, McGillivray JA, et al. Physical activity, sedentary behavior and their correlates in children with autism spectrum disorder: a systematic review. PloS One 2017; 12(2): 1-23.

[3] Shi Z-M, Lin G-H, Xie Q. Effects of music therapy on mood, language, behavior, and social skills in children with autism: A meta-analysis. Chinese Nursing Research 2016; 3(3): 137-41.

[4] Garcia-Pastor T, Salinero J, Theirs C, Ruiz-Vicente D. Obesity Status and Physical Activity Level in Children and Adults with Autism Spectrum Disorders: A Pilot Study. Journal of Autism and Developmental Disorders 2019; 49(1): 165-72.

[5] Moradimokhles H, Houshmandi Shoja M, Salehi V. Improving the Social Adjustment of Children with Attention-Deficit/Hyperactivity Disorder by Expanding the Zone of Proximal Development in the Context of Creative Drama. Journal of Exceptional Children 2018; 18(1): 73-84. [Farsi]
[6] Young S, Furgai K. Exercise effects in individuals with autism spectrum disorder: a short review. Autism Open Access 2016; 6(3): 1-2.

[7] Yaghoubi H, Karimlo M, Hajdivanbachari S. Video Games on the Behavior of Children with Autism Spectrum Disorder. Middle Eastern Journal of Disability Studies 2019; 9(1): 1-6. [Farsi]

[8] De Jaegher H. Embodiment and sense-making in autism. Frontiers in Integrative Neuroscience 2013; 7(15): 1-19.

[9] Woodman AC, Breviglia E, Mori Y, Golden R, Maina J, Wisniewski H. The Effect of Music on Exercise Intensity among Children with Autism Spectrum Disorder: A Pilot Study. Journal of Clinical Medicine 2018; 7(3): 1-12.

[10] Stins JF, Emck C. Balance performance in autism: A brief overview. Frontiers in Psychology 2018; 9(1): $1-6$.

[11] Fong CE, Jelas ZM. Music education for children with autism in Malaysia. Procedia-Social and Behavioral Sciences 2010; 9(1): 70-5.

[12] Dehghani M, Karimi N, Taghipour javan A, Hassan Nataj Jelodar F, F Z. The effectiveness of rhythmic 
motor games on the rate of executive functions in children with evolutionary neuropsychological learning disabilities before the primary school. Learning Disabilities Journal 2012; 2(1): 53-77. [Farsi]

[13] Katagiri J. The effect of background music and song texts on the emotional understanding of children with autism. Journal of Music Therapy 2009; 46(1): 15-31.

[14] Geretsegger M, Holck U, Gold C. Randomised controlled trial of improvisational music therapy's effectiveness for children with autism spectrum disorders (TIME-A): Study protocol. BMC pediatrics 2012; 12(1): 1-9.

[15] Demirci N, Engin AO, Özmen A. The Influence of Physical Activity Level on the Children's Learning Ability of Disabled Children Having Difficulties in Learning. Procedia-Social and Behavioral Sciences 2012; 69(1): 1572-8.

[16] Ghafori R, Heirani A, Aghdasi M, Ebrahimi B. Effect of Rhythmic Movements on working Memory, Motor Proficiency and Writing Skills in the Students with Dysgraphia. Journal of North Khorasan University of Medical Sciences 2019; 11(1): 23-31. [Farsi]
[17] Elliott D, Carr S, Orme D. The effect of motivational music on sub-maximal exercise. European Journal of Sport Science 2005; 5(2): 97-106.

[18] Khanjani Z, Khaknezhad Z. The effect of inactive music therapy on symptoms, communication deficit, and social interaction of children with autism spectrum disorder. Quarterly Journal of Child Mental Health 2016; 3(3): 97-105. [Farsi]

[19] Pater M, Van Yperen T. The Development of Social Behavior During Music Therapy: A Child Case Report. Int J Psychiatr Res 2020; 3(2): 1-6.

[20] Gruhn W. Phases and stages in early music learning. A longitudinal study on the development of young children's musical potential. Music Education Research 2002; 4(1): 51-71.

[21] Neely L, Rispoli M, Gerow S, Ninci J. Effects of antecedent exercise on academic engagement and stereotypy during instruction. Behavior Modification 2015; 39(1): 98-116.

[22] Ghorbanpour K, Pakdaman M, Rahmani MB, Gholamhosseini H. The effect of rhythmic movement and playing aerobic on short-term memory functionand auditory memory of students with learning disabilities. Journal of Health Breeze 2013; 1(4): 35-44. [Farsi] 
[23] Samadi SA, McConkey R. Screening for autism in Iranian preschoolers: Contrasting M-CHAT and a scale developed in Iran. Journal of Autism and Developmental Disorders 2015; 45(9): 2908-16.

[24] Duvekot J, van der Ende J, Verhulst FC, Slappendel G, van Daalen E, Maras A, et al. Factors influencing the probability of a diagnosis of autism spectrum disorder in girls versus boys. Autism 2017; 21(6): 646-58. [Farsi]
[25] Mössler K, Schmid W, Aßmus J, Fusar-Poli L, Gold C. Attunement in Music Therapy for Young Children with Autism: Revisiting Qualities of Relationship as Mechanisms of Change. Journal of Autism and Developmental Disorders 2020; 50(1): 3921-34.

[26] Trevarthen C, Delafield-Butt JT. Autism as a developmental disorder in intentional movement and affective engagement. Frontiers in Integrative Neuroscience 2013; 7(1): 1-16. 
rه • ا تأثير محيط تلفيقى موسيقى محور بر مهارتهاى رشد حر كتى در كود كان طيف اتيسم

\title{
The Effect of Music-Based Blended Environment on the Development of Motor Skills in Children with Autism: A Quasi-Experimental Study
}

\author{
$\underline{\text { H. Moradimokhles }}^{1}$, Sh. Bagheri ${ }^{2}$ \\ Received:18/05/2020 Sent for Revision: 20/06/2020 Received Revised Manuscript:02/12/2020 Accepted:07/12/2020
}

Background and Objectives: The use of integrated interventions in autistic children is expanding. Autistic children's interest in music and their ability to understand it can be effective in therapeutic interventions. This study aimed to determine the effect of a music-based integrated environment on motor development skills in autistic children.

Materials and Methods: This quasi-experimental study was of pretest-posttest control group design. Subjects were selected by convenience sampling method from among children with autism at Rozaneh Autism Center in Hamadan in 2019 and were randomly assigned to experimental and control groups. A total of 15 autistic children formed the intervention group, while 15 autistic children formed the control group. The experimental group performed a 12 week exercise program with music and the control group performed only a 12 -week exercise program. Data were collected using a demographic form, a Lincoln-Oseretsky developmental motor scale. Independent t-test and ANCOVA test were used to measure the effect of music intervention.

Results: It was found that the Lincoln-Oseretsky mean score in the intervention group in post-test was significantly higher than the pre-test $(\mathrm{p}<0.05)$.

Conclusion: Overall, it was concluded that the music-based blended environment can be effective in the development of motor skills in children with autism. Therefore, blended intervention including music along with other therapies can lead to useful results in improving the performance of children with autism.

Key words: Blended environment, Music, Motor skills, Autism

Funding: This study was funded by University of Nahavand.

Conflict of interest: None declared.

Ethical approval: The Ethics Committee of Nahavand University approved the study (IR.NAHGU.REC.1398.001).

How to cite this article: Moradimokhles H, Bagheri Sh. The Effect of Music-Based Blended Environment on the Development of Motor Skills in Children with Autism: A Quasi-Experimental Study. J Rafsanjan Univ Med Sci 2021; 19 (10): 1035-52. [Farsi]

1- Assistant Prof., Educational Sciences Dept., Literature \& Human Sciences Faculty, Bu-Ali Sina University, Hamedan, Iran, ORCID: 00000003-3802-5660

(Corresponding Author) Tel: (081) 38292614, Fax: (081) 38292614,E-mail: moradimokhles@basu.ac.ir

2- Assistant Prof. of Sport Injuries, Dept. of Sport Sciences, Faculty of Sport Sciences, University of Nahavand, Nahavand, Iran, ORCID: 0000-0002-8944-2176

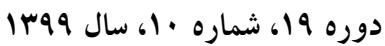

مجله دانشگاه علوم يزشكى رفسنجان 